Apidologie, 1977, 8 (2), 205-216.

\title{
UNUSUAL INTERTROPHOCYTIC POSITION OF FOLLICLE CELLS IN THE NURSE CHAMBER OF THE HONEYBEE QUEEN OVARY (APIS MELLIFICA)*
}

\author{
P. S. RAMAMURTY** \\ Lehrstuhl Entwicklungsphysiologie, Institut für Biologie III (Zoologie) der Universität Tübingen \\ Auf der Morgenstelle 28, D-7400 Tübingen 1
}

\section{SUMMARY}

The follicle cells normally form an envelope around the ovarian follicles. In the meroistic polytroph insect ovarioles, they enclose the nurse chamber and the oocyte. In the ovaries of Apis mellifica queens, besides an inconspicuous follicle epithelial envelope on the periphery of the nurse chamber, single medial follicle cells were found centrally between the trophocytes. This is an anomalous situation for the follicle cells.

The origin of the medial intertrophocytic follicle cells can be observed in very young follicles. During follicle formation single cells from the incipient peripheral follicle epithelium detach themselves from the basement membrane and migrate inwards. In the electron micrographs, these intertrophocytic medial follicle cells always exhibit typical follicle cell structure. They posess all the usual cell organelles, especially lysosomes, and are clearly distinguishable as hyaline cells from the surrounding trophocytes.

It is suggested that these cells may play a role in bringing about a rapid degeneration of the nurse chamber towards the end of vitellogenesis. Because of the high rate of egg-production an undelayed breakdown of the non-generative cells must occur.

\section{INTRODUCTION}

In the polytrophic ovarioles of insects, the egg development is supported by the trophocytes, in addition to the follicle epithelial cells. The nurse chamber forms a cap above the corresponding oocyte and consists of a varied, but species specific number of trophocytes. They bear large endopolyploid,

* With financial support of the Deutsche Forschungsgemeinschaft to Prof. Dr. Wolf Engels.

** Permanent Adress : Department of Zoology, Banaras Hindu University, Varanasi - 221 005, India. 
irregularly shaped nuclei, which are the main centres of RNA synthesis that is supplied to the oocyte (Bier, 1963, 1964; Ramamurty, 1963; Engels, 1968; Pollack and Telfer, 1969). Besides RNA, the trophocytes in Apis produce various cell organelles like ribosomes, mitochondria, lipid droplets and vesicles, which move towards the oocyte across the fusomes (RAmamurty, 1977). The trophocytes are derived from the germ line and are differentiated from the cystoblasts in the posterior region of the germarium (Telfer, 1975). They remain connected with each other and with the oocyte below, by means of fusomes or intercellular bridges that result from incomplete cytokineses of the cystocytes (FAWCETT et al., 1959).

The follicle epithelial cells form an envelope around the nurse chamber and the oocyte. They arise from repeated mitotic activity of the prefollicular tissue in the posterior region of the germarium and are generally believed to be of somatic origin (Bonhag, 1958). In the different regions of a follicle, the follicle epithelium undergoes varied functional differentiation. Thus, the layer enclosing the nurse chamber has no known function and hence is made up of an inconspicuous epithelial layer of greatly attenuated, elliptical cells. On the other hand, the follicle epithelial cells investing the oocyte, first mediate the transport of haemolymph yolk protein (vitellogenin) to the oocyte cortex (Bier, 1962; Ramamurty, 1964; ENgels, 1973) and at the cessation of vitellogenesis they secrete the chorion. In accordance with this, the follicle epithelium enveloping the egg chamber is always well-developed and continuously adapts itself to the growing volume of the oocyte, both by mitotic multiplications and structural transformations.

In light and electron microscopic studies of Apis queen ovaries, some follicle cells have been found in unusual positions, namely, in the intercellular spaces between the trophocytes in the nurse chamber. The origin, topography and structure of these anomalous cells is described here and a hypothesis on their possible functional significance is presented.

\section{MATERIALS AND METHODS}

For light microscopic studies, the ovaries of Apis mellifica were fixed in Bouin-Allen-Bauer mixture and paraplast sections of $7 \mu \mathrm{m}$ were stained either with azur B or with Heidenhain's haematoxylin-eosin. For electron microscopy, the ovarioles were fixed for $1 \mathrm{~h}$ in $2.5 \%$ glutaraldehyde in $0.2 \mathrm{M}$ sodium cacodylate and $0.1 \mathrm{M}$ sucrose adjusted to $\mathrm{pH}$ 7.4. Materials were post fixed in $2 \%$ osmium tetroxide for $1 \mathrm{~h}$ and embedded in epon. Semithin sections of $1 \mu \mathrm{m}$ were stained with toluidine blue and examined with light microscope. Ultrathin sections were contrasted with uranyl acetate and lead citrate. Grids were examined under Siemens Elmiskop 102 at $60 \mathrm{KV}$. 


\section{RESULTS}

The egg development in Apis mellifica queens takes place in 6 welldefined stages of oogenesis (ENGELS, 1973). Stage $O$ is the phase of follicle formation, beginning in the posterior region of the germarium. Up to stage 3, the nurse chamber is larger than the corresponding oocyte. From stage 3 onwarls, the oocyte increases in volume due to intense and rapid yolk incorporation. In stage 5 , the vitellogenesis is completed and the vitelline membrane is formed on the oocyte surface. The follicle epithelium secretes the chorion at the end of this stage. During stage 6 , the follicle epithelium degenerates and thereafter, the egg is ready for oviposition.

The nurse chamber is made up of 47 trophocytes arranged in 5 vertical rows (Paulcke, 1901; Engels, 1968). In the young follicles of stage O, in the lower region of the germarium, the trophocytes show a spherical or oval shape with large rounded nuclei (Fig. 1). They have intercellular spaces of remarkable dimensions. But when the follicles descend into the vitellarium, the trophocytes rapidly increase in volume by endopolyploid growth of their nuclei (ENGELs, 1968) and become tightly packed, due to which they assume polygonal shapes (Fig. 2). However, small triangular crevices still occur at the trijunctions between three trophocytes. Within these spaces, a single median cell with prominent nucleus is seen here and there (Figs. 2 and 3). The question arises whether the occurrence of intertrophocytic cellular elements is a regular or only an accidental phenomenon, and what might be the origin and significance of these cells.

A careful examination of the structure of young follicle in formation (stage 0 ) shows that some of the peripherally situated follicle epithelial cells assume pear-like shape typical for migratory cells (Fig. 1). The only possible interpretation is that these cells detach themselves from the tunica propria and migrate inwards. Follicle cells that have already reached the centre of the nurse chamber can be clearly distinguished by two special properties : They are smaller and have elliptical nuclei while the nurse cells posses large spherical nuclei, and in the semithin sections stained with toluidine blue the medial follicle cells appear brighter than the surrounding trophocytes which react more basophilic. Medial follicle cells are found in any section of a nurse chamber in all stages of oogenesis (Fig. 3). It therefore seems highly probable that these cells should have a special function in the physiology of follicle development. For further information the ultrastructure was analysed.

In the electron micrographs, the medial intertrophocytic follicle cells appear as hyaline areas in the trijunctions between 3 neigh-bouring trophocytes 


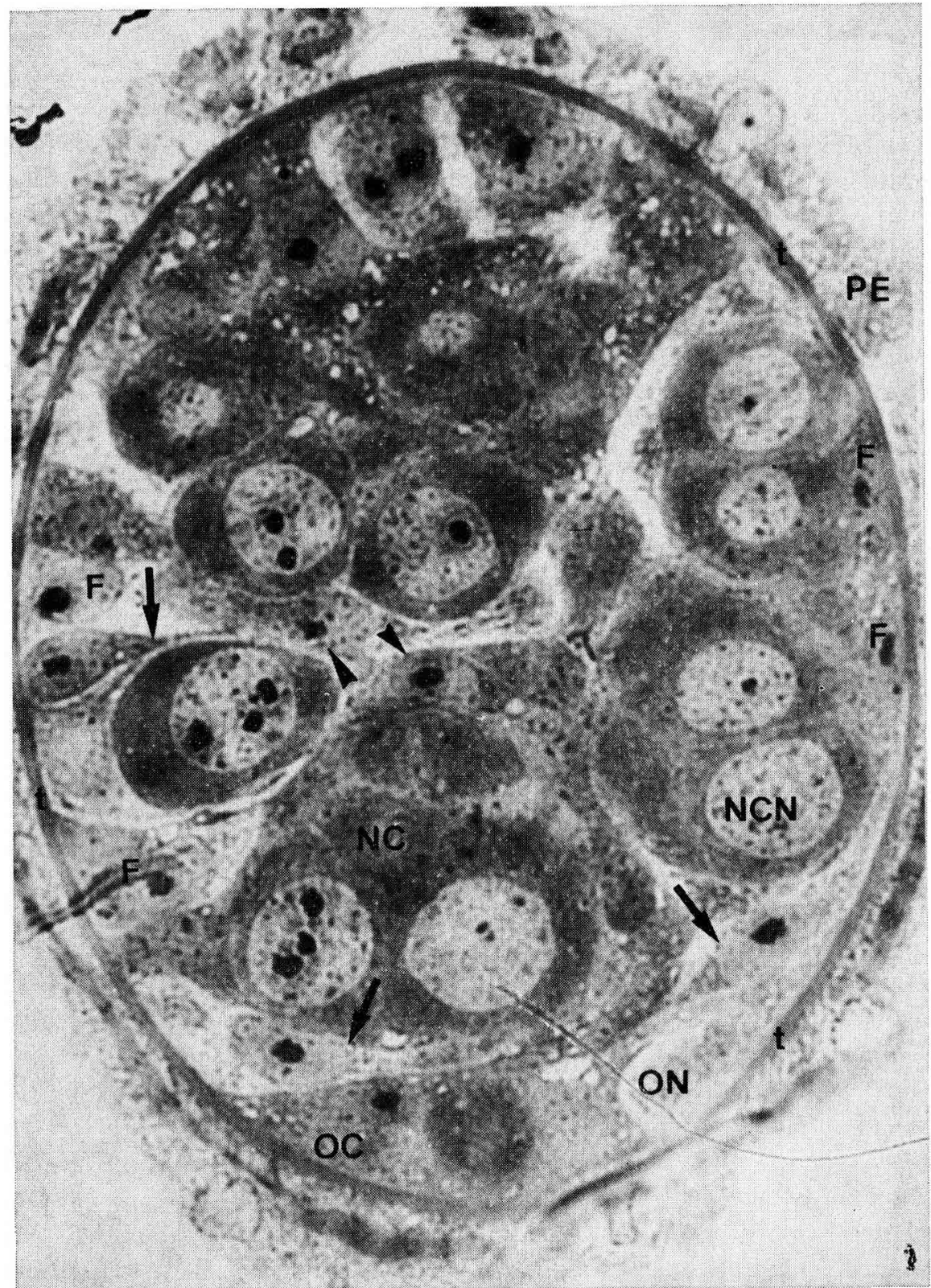

Fig. 1. - Follicle of stage 0 from the honeybee queen ovary.

Toluidine blue stained semi-thin section showing the nurse chamber with several trophocytes (NC $=$ nurse cells) bearing large spherical nuclei $(\mathrm{NCN}=$ nurse cell nucleus). Note the large intercellular spaces between the trophocytes. Some medial follicle cells $(-)$ have already reached the centre of the nurse chamber, while others are in the process of migration $(->) . F=$ follicle epithelial cells, $\mathrm{OC}=$ young oocyte, $\mathrm{ON}=$ oocyte nucleus, $\mathrm{PE}=$ peritoneal epithelium; $t=$ tunica propria. $\times 850$. 


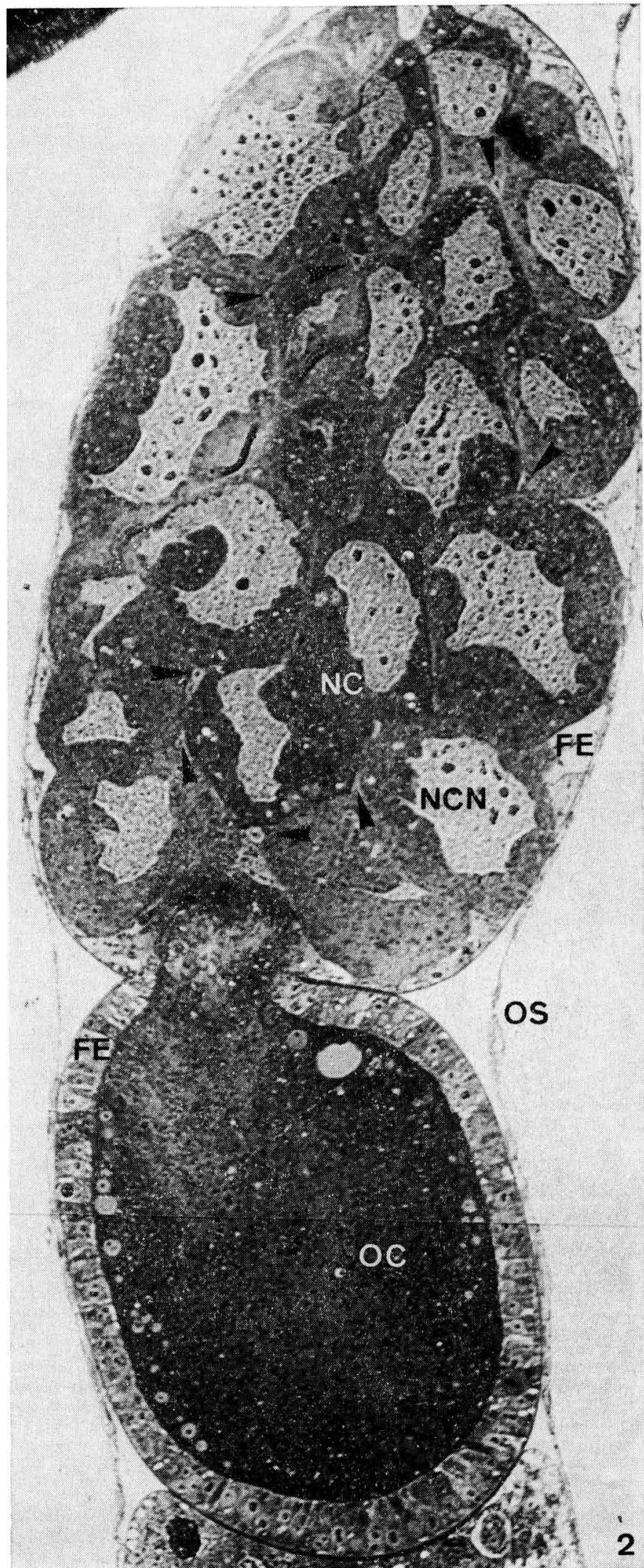




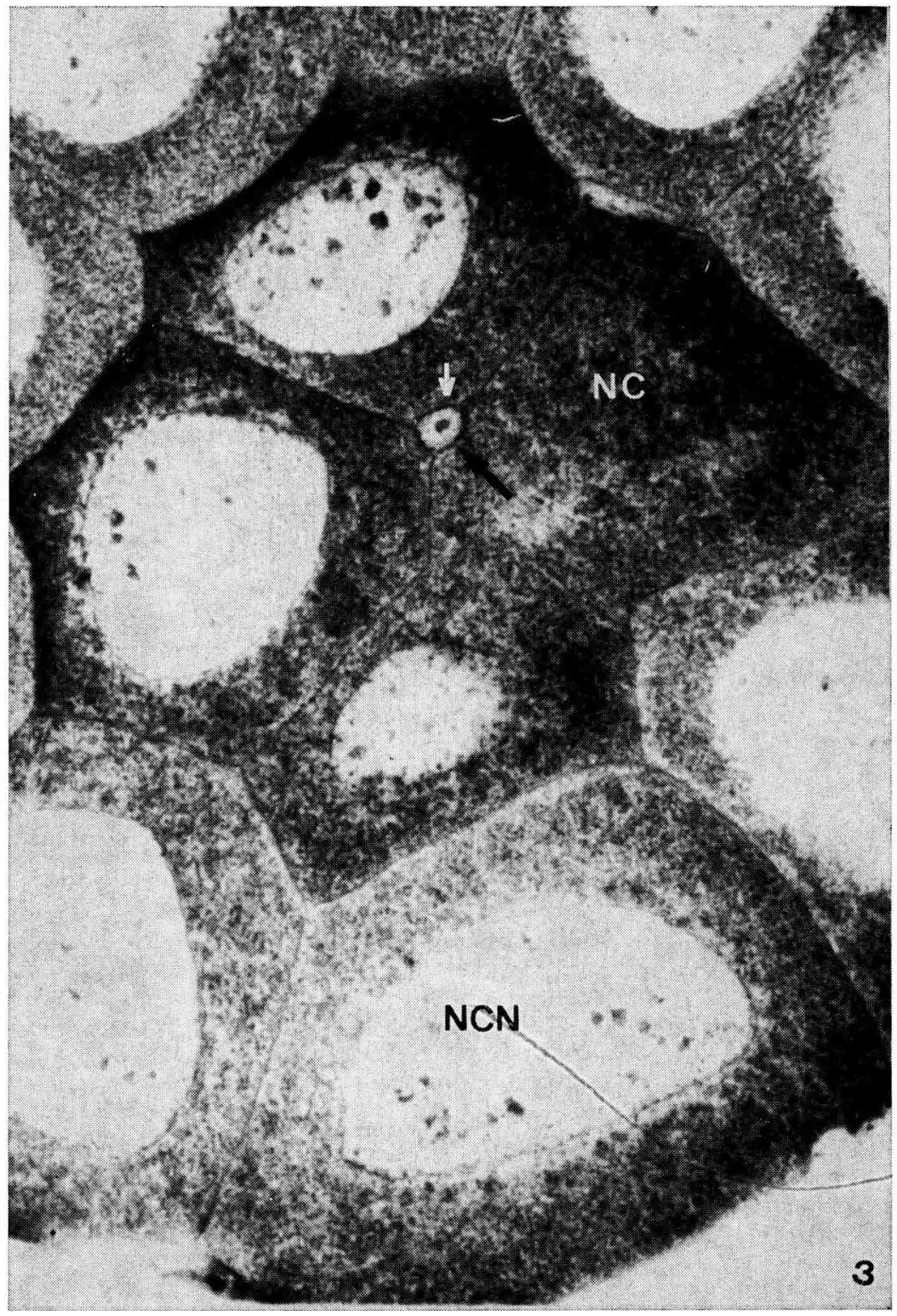

Fig. 3. - Follicle of stage 3 from the honeybee queen ovary.

Paraffine section through the nurse chamber, showing some of the polygonal trophocytes (NC = nurse cell) with large polyploid nuclei (NCN $=$ nurse cell nucleus) and basophilic cytoplasm rich in ribosomes. In the intercellular space, a medial follicle cell $(\longrightarrow)$ is clearly visible. Bouin-Allen-Bauer/Azur B. $x$ 850. 
(Fig. 4). In their cytoplasm, all the usual cell organelles, like mitochondria, ribosomes, endoplasmic reticulum, microtubules, golgi vesicles and especially lysosomes are recognisable.

So they exhibit a normal and functional aspect. A remarkable number of large lysosomes can be observed in the medial follicle cells of stage 4 . The trophocytes lack lysosomes. An elliptical nucleus occurs in the medial follicle cells, which is evidently an adaptation to their shape. The mitochondria in the medial follicle cells are of much larger size, as compared with those in the nurse cell cytoplasm. The density of ribosomes is greater in the trophocytes than in the medial follicle cells. The cell membranes of the trophocytes surrounding the medial follicle cell, show convolutions and elsewhere the membranes exhibit even surface.

\section{DISCUSSION}

The trophocytes have a short span of life, during which in stages 1-4 they undergo an enormous increase in volume by endopolyploidy, synthesize RNA at a high tempo and produce several cell organelles that are exported to the oocyte. In stage 5, when the vitellogenesis in a follicle ceases (EnGELs, 1973), the entire nurse chamber suddenly collapses and shrinks in volume and the remnants of the degenerating nurse chamber are extruded into the oocyte (Engels, 1968). This process which takes place very rapidly, is termed by Telfer (1975) as the terminal injection. The question arises, as to how this sudden degeneration of the nurse chamber is brought about.

King (1970) has described for Drosophila the immigration of peripheral cells from the follicle epithelium into the nurse chamber where they form cell clusters. These cells later move down the nurse chamber and take up definitive position at the nurse chamber-oocyte border. He interpreted these medial follicle cells to be involved in the formation of the micropylar apparatus. In Apis, however, no micropylar apparatus is found. Moreover, the medial follicle cells in the honeybee do not form cell clusters but exist mostly as individual cells between the trophocytes (Fig. 2 and 3). As such, the immigrated follicle cells in the honeybees must have some other function.

It is generally known that in atretic ovarian follicles, the follicle cells surrounding the oocyte become thickened and enlarge, then turn phagocytic and ingest the ooplasma, including yolk spheres from the degenerating oocyte. This was demonstrated for Musca domestica by Trepte-Federborn (1969) and for the zebra fish, Brachydanio by Korfsmeier (1969). The same observation was made in Apis (RAmamurTy, unpublished). It indicates that the follicle cells which have a large number of lysosomes are capable of phagocytosis and can bring about the disruption of other pycnotic cells by invasion. 


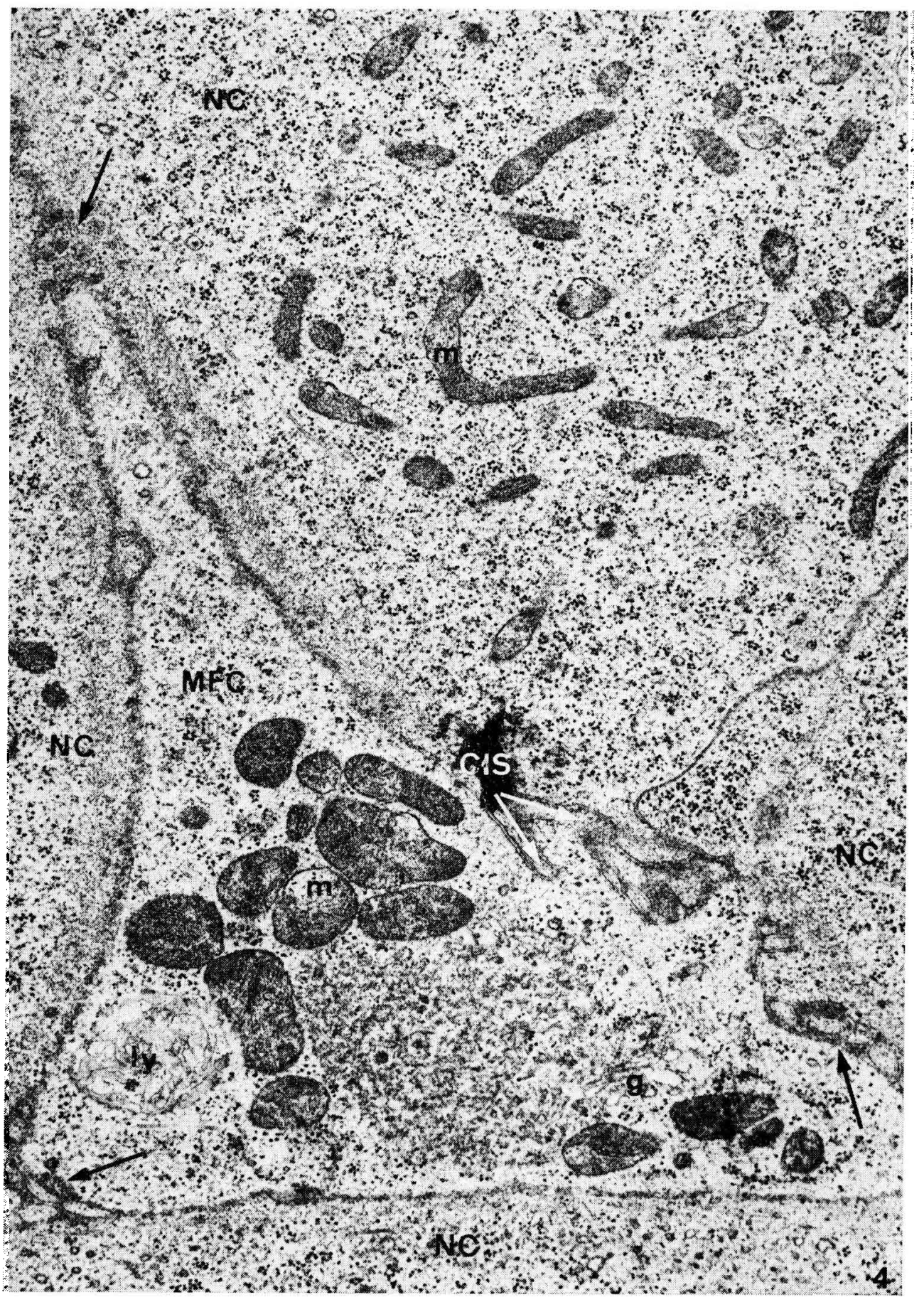

FiG. 4. - Follicle of stage 4 from the honeybee queen ovary.

An electron micrograph showing a part of the nurse chamber with a trijunction between four adjacent trophocytes $(\mathrm{NC}=$ nurse cell) including a triangular-shaped medial follicle cell (MFC). The membranes bounding the intercellular spaces of the trophocytes adjacent to the medial follicle cell are convoluted (CIS $=$ convoluted intercellular space $\rightarrow$ ). The usual cell organelles like mitochondria $(m)$, golgi apparatus (g), microtubules, ribosomes, lysosomes (ly) are recognisable. Note the size of the mitochondria in the medial follicle cell, as compared with those of the trophocytes. $x 18,000$. 
Moreover, the follicle cells themselves normally degenerate by autolysis in stage 6, presumably also by activation of lysosomes. This takes place after building up the vitelline membrane by the oocyte and the chorion by the follicle epithelium (ENGELS, 1973).

By the terminal injection, most of the nurse cell contents reach the oocyte. In Apis, as in majority of polytrophic insects (TELfER, 1975) the remaining trophocyte nuclei in the degenerating nurse chamber in stage 5 are surrounded by little cytoplasm.

During the season of rapid increase in the size of the colony, the honeybee queen may lay as many as 2000 eggs per day. Since both the ovaries together contain approximately 350 ovarioles, a daily output of 5-10 follicles per ovariole could be calculated. In other words, ovulation takes place every 3-5 hours in an ovariole (ENGELs, 1973). Such a high rate of egg-production makes it necessary to have a mechanism for speedy disposal of remnants of degenerating nurse chambers, which otherwise would block the maturation of the next follicles.

In the trophocyte cytoplasm, the present electron microscopic studies failed to show any lysosomes that could autolyse the nurse cells. On the other hand, all the follicle cells, including the medial ones situated in between the trophocytes possess lysosomes in considerable numbers. It ist therefore presumable that the lysosomes in the medial follicle cells become activated in stage 5 and these may cause the sudden collapse and degeneration of the trophocytes.

This hypothesis would explain the unusual position of the intertrophocytic follicle cells which are described here in the honeybee ovary for the first time in insects. It is yet unknown whether such medial follicle cells are present in other species too. Perhaps they are in social Hymenoptera with similar frequences of egg-production as in Apis. Such a mechanism for the disruption of the nurse chamber is not necessary in the Termites, because the Isoptera have follicle of the panoistic type without nurse cells. After the phagocytic uptake of the trophocyte remnants, the medial follicle cells as well as those investing the oocyte and nurse chamber themselves probably undergo autolysis in stage 6 and disappear.

This functional interpretation of the role of the medial follicle cells in egg development needs further studies.

Reçu pour publication en fêvrier 1977.

\section{ACKNOWLEDGEMENTS}

Grateful acknowledgements are made to Prof. Dr. Wolf Engess for providing the working space in his laboratory and for critically reading the manuscript. Thanks are due to Dr. F. BARDELE for extending the electron microscope facility, to Dr. U. MaYs and Mr. 
M. Lacombe for introducing me in several EM techniques, to Miss Anne Vees and Miss Eva Sonemann for help in ultramicrotomy, and to Miss Margret Schürmann and Mr. P. Börsch in handling the experimental queens. The Alexander von Humboldt-Stiftung has generously provided financial support, which made this work possible.

\section{ZUSAMMENFASSUNG}

\section{UNGEWÖHNLICHE INTERTROPHOCYTÄRE LAGE VON FOLLIKELZELLEN IM NÄHRFACH DES BIENENKÖNIGIN-OVARS (Apis mellifica)}

Eifollikel sind normalerweise von Epithelzellen umhüllt. Beim polytrophmeroistischen Typ der Insektenovariolen schließt ein einschichtiges Follikelepithel außer der Oocyte das Nährfach ein. Im Ovar der Bienenkönigin (Apis mellifica) wurden neben einer sehrdünn ausgezogenen äußeren Follikelepithelhülle um das Nährfach einzelne mediale Follikelzellen innen zwischen den Nährzellen gefunden. Eine solche Lage ist für Follikelzellen aufergewöhnlich. Nur von Dipteren ist bekannt, daß Gruppen von Follikelzellen zwischen den Nährzellen hindurch an die Grenze Nährfach - Oocyte wandern, wo sie gegen Ende der Oogenese im Zusammenhang mit der Chorion-Synthese die Mikropylen ausbilden. Da derartige Strukturen am Bienenei nicht vorhanden sind und außerdem die gefundenen medialen Zellen stets einzeln liegen, stell, sich die Frage nach ihrem Urprung und ihrer Funktion.

An sehr jungen, sich gerade formierenden Apis-Follikeln kann beobachtet werden, daß einzelne Zellen des sich bildenden Follikelepithels sich von der tunica propira ablösen und ins Nährfach-Innere einwandern. Sie finden sich später in den Zwickeln des Interzellularraumes der Nährzellen. Die Ultrastruktur dieser stärker hyalinen medialen Zellen, die einen funktionstüchtigen Eindruck machen, stimmt mit der des peripheren Follikelepithels überein. Die normalen Zellorganellen sind vorhanden. Kennzeichnend ist (neben grösseren Mitochondrien als in den Nährzellen) das Vorkommen von Lysosomen, die den Nährzellen völlig fehlen.

Es ist bekannt, daß Zellen des Follikelepithels atretische Follikel phagocytär auflösen. Bei der Bienenkönigin besteht das Probelm einer raschen Nährfach-Degeneration, wenn bei intensiver Eiablage pro Ovariole alle 3-5 Stunden ein Follikel reift. Es wird die Arbeitshypothese aufgestellt, da 3 nach Ende der Vitellogenese-Phase die medialen Follikelzellen die Aulösung der Nährfach-Reste besorgen, soweit diese nicht in die Oocyte gelangen. Zum Schluß der Oogenese wird eine Autolyse sowohl der medialen wie der epithelialen Follikelzellen angenommen.

Diese funktionelle Interpretation der bei anderen Insektenarten noch nicht gefundenen einzelnen medialen Follikelzellen bedarf weiterer experimenteller Überprüfungen.

\section{RÉSUMÉ}

POSITION INTERTROPHOGY'TAIRE INHABITUELLE DES CELLULES FOLLICULAIRES DANS LA CHAMBRE NUTRITIVE DE L'OVAIRE DE LA REINE D'ABEILLE (Apis mellifica)

Les follicules ovariens sont habituellement enveloppés de cellules épithéliales. Dans les ovarioles d'insectes de type polytropho-méroistique, une couche de cellules épithéliales folliculaires entoure la chambre nutritive et l'oocyte. Dans l'ovaire de la reine d'abeille (Apis 
mellifica) on trouve, à côté d'une enveloppe épithéliale folliculaire externe très peu apparente, des cellules folliculaires isolées, médianes, situées autour de la chambre nutritive. Cette situation est tout à fait inhabituelle pour des cellules folliculaires. Ce n'est que chez les Diptères que l'on a trouvé des groupes de cellules folliculaires qui migrent entre les trophocytes jusqu'à la limite chambre nutritive-oocyte, où elles constituent les micropyles à la fín de l'ovogenèse en relation avec la synthèse du chorion. Puisque de telles structures sont absentes de l'ouf d'abeille et que, par ailleurs, les cellules médianes trouvées restent toujours isolées, leur origine et leur fonction se posent.

Dans les follicules très jeunes et en cours de formation d'Apis on peut observer que les cellules isolées de l'épithélium folliculaire se détachent de la tunica propria et migrent à l'intérieur de la chambre nutritive. On les retrouve plus tard dans les coins de l'espace intercellulaire des trophocytes. L'ultrastructure de ces cellules médianes fortement hyalines, qui ont un aspect fonctionnel, coincide avec celle de l'épithélium folliculaire périphérique. Les organites cellulaires normaux sont présents. Ces cellules possèdent des mitochondries de plus grande taille que les trophocytes et la présence de lysosomes est caractéristique, alors qu'ils sont totalement absents des trophocytes.

On sait que les cellules de l'épithélium folliculaire dans les follicules atrétiques sont capables de phagocytose. Chez la reine d'abeille se pose le problème de la dégénération rapide de la chambre nutritive, lorsque dans chaque ovariole un follicule mûrit toutes les 3-5 heures pendant la période de ponte intensive. On émet l'hypothèse de travail selon laquelle les cellules folliculaires médianes sont responsables de la résorbtion des restes de la chambre nutritive à la fin de la phase de vitellogenèse, dans la mesure où ceux-ci n'atteignent pas l'oocyte. A la fin de l'ovogenèse on admet l'existence d'une autolyse des cellules folliculaires tant médianes qu'épithéliales.

Cette interprétation fonctionnelle des cellules folliculaires médianes isolées, que l'on n'avait pas encore trouvées chez d'autres espèces d'insectes, requiert des vérifications expérimentales ultérieures.

\section{R EFER ENCES}

Bien K., 1962. - Autoradiographische Untersuchungen zur Dotterbildung. Naturwiss., $49,332-333$.

Bren K., 1963. - Synthese, interzellulärer Transport und Abbau von Ribonukleinsäure im Ovar der Stubenfliege Musca domestica. J. Cell Biol., 16, 436-440.

BıER K., 1964. - Gerichteter Ribonukleinsäuretransport durch das Cytoplasma. Naturwiss., $51,418-419$.

Bonhag P. F., 1958. - Ovarian structure and vitellogenesis in insects. Annu. Rev. Entomol. 3 , 137-160.

Engels W., 1968. - Extraoocytäre Komponenten des Eiwachstums bei Apis mellifica. I. Trophocytäre RNS-Zufuhr. Insectes Soc., 15, 271-288.

Engels W., 1973. - Das zeitliche und räumliche Muster der Dottereinlagerung in die Oocyte von Apis mellifica. Z. Zellforsch., 142, 409-430.

Fawcett D. W., Ito S. and Slautterback D., 1959. - The occurrence of intercellular bridges in groups of cells exhibiting syncytial differentiation. J. biophys. biochem. Cytol., 5, 453460.

KING R. C., 1970. - Ovarian development in Drosophila melanogaster. - Academic Press, New York and London.

Konfsmeier K. H., 1969. - Über die Degeneration von Fizellen des Zebrafisches Brachydanio in vitro. Z. Zellforsch., 98, 99-105. 
Paulcke W., 1901. - Über die Differenzierung der Zellelemente im Ovarium der Bienenkönigin. Zool. Jb. Anat., 14, 177-202.

Pollack S. B. and Telfer W. H., 1969. - RNA in Cecropia moth ovaries : Sites of synthesis, transport and storage. J. exp. Zool., 170, 1-24.

Ramamurty P. S., 1963. - Über die Herkunft der Ribonukleinsäure in den wachsenden Eizellen der Skorpionsfliege Panorpa communis (Mecoptera). Naturwiss., 50, 383-384.

Ramamurty P. S., 1964. - On the contribution of the follicle epithelium to the deposition of yolk in the oocyte of Panorpa communis (Mecoptera). Exp. Cell Res., 33, 602-605.

Telfer W. H., 1975. - Development and Physiology of the Oocyte-Nurse Cell Syncytium. Adv. Ins. Physiol., 11, 223-319.

Trepte-Feuerborn Ch., 1969. - Der Einfluß larvaler und imaginaler Ernährung auf die Atresie im Fliegenovar. Staatsexamenarheit, Zoolog. Institut der Univ. Münster (Westf.) 